\title{
Implikatur dalam Percakapan Tertulis Bahasa Inggris SMA
}

\author{
Oleh: \\ Sudirman \\ Prodi Pendidikan Bahasa Inggris \\ Fakultas Keguruan dan Ilmu Pendidikan Universitas Lampung \\ Email: sudirmanmuhdi@yahoo.com
}

\begin{abstract}
This article presents a study of implicature in written English conversation. Up to the present, there has not been a research carried out on written English conversation, while there are many conversation units written in Senior High School (SMA) Sdudents` book. This study, therefore, was aimed at describing the types of implicature in written conversation in SMA students' book. The source of data was accordingly taken from a conversation unit written in SMA student's book entitled English Alive Senior High School published by Yudistira. From this book, one topic of conversation was taken then analized using pragmatical conversational schame to find the types of implicature implied in it. The result of the analysis showed that there were fifteen implicature types used by conversational locuters. The fifteen types of implicatures were mainly lingual in form of word, phrase, clause, and sentence.
\end{abstract}

Keywords: written conversation, implicature, lingual 


\section{PENDAHULUAN}

Bahasa Inggris telah lama dipelajari di sekolah-sekolah sebagai pelajaran yang bertujuan untuk membekali para siswa mampu berkomunikasi secara global. Komunikasi dalam Bahasa Inggris menurut KTSP (Kurikulum Tingkat Satuan Pendidikan) atau sebelumnya disebut KBK (Kurikulum Berbasis Kompetensi) dilakukan melalui empat keterampilan berbahasa: listening, speaking, reading, and writing.

Penyajian materi dalam bahasa Inggris secara pragmatik masuk dalam semua kegiatan belajar berbahasa untuk meningkatkan keampuan para siswa dalam berkomunikasi dengan bahasa Inggris. Pada dasarnya pembahasan bahan pragmatik berada dalam setiap aspek pengajaran bahasa Inggris baik di SMP maupun di SMA yang berorientasi pada kegiatan belajar menggunakan bahasa. Hal ini berarti bahwa pembahasan pragmatik menjiwai seluruh segi-segi pengajaran bahasa Inggris yang ditampilkan dalam tema-tema yang menganut azas kesederhanaan, kebermaknaan, kewajaran, konteks, keluwesan (disesuaikan dengan kebutuhan dan kondisi setempat), keterpaduan dan kesinambungan berbagai segi dalam keterampilan berbahasa (Depdikbud, 1994).

Dalam rambu-rambu Kurikulum Berbasis Kompetensi (KBK) / Kurikulum 2004 untuk SMA (Depdiknas, 2003) ditegaskan bahwa pembelajaran bahasa Inggris ditekankan bukan pada pengetahuan tentang bahasa, melainkan pada keterampilan berbahasa: listening, speaking, reading, dan writing. Dengan demikian, dapatlah dipertegas bahwa penyampaian materi pelajaran bahasa Inggris secara pragmatik semakin penting. Hal ini sesuai dengan apa yang di kemukakan oleh Nababan (1987) bahwa pragmatik membawa pengkajian bahasa lebih jauh ke dalam keterampilan menggunakan bahasa untuk komunikasi praktis dalam segala situasi yang mendasari interaksi kebahasaan antar manusia sebagai anggota masyarakat. Jadi, jika tujuan mempelajari bahasa Inggris menjadikan para pemelajar (siswa) sebagai komunikator yang betul-betul efektif di dalam bahasa kedua atau asing yanfg sedang dipelajari, seperti bahasa Inggris, mereka harus menyadari aturan-aturan kepatutan dalam budaya bahasa yang dipelajari (Refnaldi, 2009). Aturan kepatutan itu dapat dikaji melalui kajian pragmatik. Oleh karena itu, kajian pragmatic perlu mendapat perhatian yang lebih layak dari kalangan pendidik (khususnya para guru bahasa Inggris). Perhatian demi pengembangan pragmatik dalam pengajaran bahasa Inggris perlu untuk segera ditindaklanjuti melalui penelitian. 
Penelitian implikatur ini terfokus pada implikatur yang terdapat dalam dialog tertulis (conversational implicature) bahasa Inggris yang ada di dalam buku pelajaran yang dipakai di SMA. Hal ini didasarkan pada kenyataan bahwa banyak materi ajar berupa wacana dialog (conversation) yang harus dipahami dan di praktekan oleh para siswa sebagai pembelajar bahasa Inggris di sekolah yang berada dlam tahap belajar bahasa secara formal. Berdasarkan pengamatan yang belum mendalam terhadap beberapa wacana dialog buku teks pelajaran bahasa Inggris SMA, terdapat implikatur baik lingual maupun kontekstual. Bahasa Inggris yang digunakan dalam dialog tertulis tersebut telah diwarnai dengan berbagai macam implikatur yang cukup menarik untuk dikaji dan diteliti. Selain hal itu dapat ditambahkan bahwa pengajaran bahasa Inggris di SMA masih belum memasukkan implikatur sebagai bahan pelajaran, atau paling tidak sebagai salah satu topik bahasan untuk dapat menyadarkan para pembelajar akan pentingnya implikatur dalam berkomunikasi yang efektif.

Disamping faktor penguasaan materi komponen bahasa secara linguistik dan keterampilan berbahasa (listening, speaking, reading, dan writing) para pembelajar bahasa Inggris juga belum secara simultan menggunakan prinsip-prinsip speech act dalam komunikasi baik lisan maupun tulis. Dengan penelitian ini akan membantu para siswa dan guru yang belajar dan mengajar bahasa Inggris untuk mengetahui pentingnya implikatur dalam percakapan.

Penelitian ini bertujuan untuk mendeskripsikan bagaimana seluk beluk, bentuk, dan keterkaitan implikatur yang terdapat dalam dialog tertulis bahasa Inggris yang ada dalam buku teks pelajaran bahasa Inggris SMA dan bagaimana implikatur percakapan tertulis itu diekspresikan.

Pragmatik sebagai suatu kajian muncul dari pandangan Morris (1938) dalam Levinson (1987) tentang semiotic, yaitu ilmu yang mempelajari sistem tanda atau lambang. Morris membagi semiotik ke dalam tiga cabang ilmu : sintaksis, semantik, dan prakmatik (lihat juga Harnish, 1991). Sintaksis mempelajari hubungan antara lambang dengan lambang lainnya. Semantik mempelajari hubungan antara lambang dan objeknya. Sedangkan pragmatik mempelajari hubungan antara lambang dengan penafsirnya (Levinson, 1987).

Batas-batas antara semantik dan pragmatik tidak sesederhana yang terungkap dengan definisi Morris itu. Keduanya memang sama-sama menggeluti makna. Perbedaan 
keduanya diungkapkan oleh Kaswanti Purwo (1990) bahwa pragmatik adalah telaah mengenai segala aspek makna yang tidak tercakup oleh teori semantik. Makna yang ditelaah pragmatik adalah makna setelah dikurangi oleh makna yang ditelaah oleh semantik. Semantik menelaah ilmu kalimat, sedangkan pragmatik menelaah makna tuturan. Kalimat adalah maujud abstrak seperti didefinisikan dalam teori tata bahasa, sedangkan tuturan adalah ujaran kalimat yang ada pada konteks yang sesungguhnya. Dengan demikian, semantik menggeluti makna kata atau klausa yang bebas konteks, sedangkan pragmatik menggeluti makna yang terikat konteks.

Leech (1989) pun menyatakan hal yang sama bahwa pragmatik sebagai suatu ilmu yang mengkaji makna tuturan, sedangkan semantik mengkaji makna kalimat. Pragmatik mengkaji makna dalam hubungannya dengan situasi ujaran. Diuraikan lebih lanjut oleh Leech bahwa situasi ujaran terdiri dari unsur-unsur : penyapa dan yang disapa, konteks, tujuan, tindak ilokusi dan tuturan; juga unsur waktu dan tempat. Konteks diartikan sebagai aspek-aspek yang terkait dengan lingkungan fisik dan social sebuah tuturan. Konteks adalah setiap tuturan latar belakang yang samasama dimiliki oleh penutur dan petutur dan yang sangat membantu petutur menafsirkan makna tuturan. Pragmatik merupakan kajian baru yang mendobrak kemapanan pandangan structural yang dipelopori oleh Chomsky. Para pengikut structural menyusun teori bahasa dengan mengabstrakkan dan mengidealkan kalimat sebagai data. Data yang digunakan berupa kalimat yang diidealkan, yaitu kalimat sempurna yang dibebaskan dari kesalahan, bukan kalimat dalam pemakaian. Pandangan strukturalis ini ditentang oleh pragmatik, yang memandang bahwa kalimat pada hakikatnya berkonteks dan kalimat ada karena digunaka dalam komunikasi. Ditegaskan oleh Kaswanti Purwo (1990) bahwa upaya menyusun teori bahasa, disamping didasarkan pada bentuk, hendaknya juga pada konteks yang meliputi penggunaan pada komunikasi, dan interaksi antara penutur dan petutur.

Selanjutnya diungkap oleh Kaswanti Purwo (1990) bahwa pada sisi lain. Sosiolinguistik yang juga telah mempertimbangkan konteks mendobrak aliran structural dalam masalah penghomogenan bahasa. Pengabstraksian data kalimat berupa kalimat ideal yang sempurna seperti dilakukan strukturalis pada dasarnya usaha penghomogenan bahasa. Menurut penganut sosiolinguistik, bahsa pada hakikatnya heterogen. Keanekaragaman bahasa terjadi dan ada karena memang terdapat latar belakang social penuturnya yang berbeeda-beda. 
Lingkup telaah pragmatik tampak belum ada kesepakatan. Levinson (1987) dalam bukunya Pragmatiks menguraikan bahwa kajian pragmatikmeliputi : deiksi, implikatur percakapan, praanggapan, tindak bahasa, dan struktur percakapan. Dalam kaitan ini Nababan (1987) dalam bukunya menguraikan kajian pragmatikmeliputi :variasi bahasa, implikatur percakapan, teori deiksis, dan praanggapan (lihat juga Suyono, 1990). Di samping ada perbedaan, pendapat-pendapat tersebut mempunyai banyak kesamaan dan semua menyatakan bahwa iplikatur percakapan merupakan aspek kajian pragmatik.

Nababan (1987) menulis bahwa agaknya konsep yang paling penting dalam ilmu pragmatik dan yang paing menonjolkan pragmatik sebagai cabang ilmu bahasa ialah konsep implikatur percakapan.

Levinson (1987) melihat bahwa menonjolnya implikatur percakapan dalam pragmatik disebabkan oleh adanya beberapa sumbangan implikatur. Pertama, implikatur percakapan mampu memberikan penjelasan fungsional yang bermakna terhadap fakta-fakta kebebasan. Kedua, implikatur memberikan penjelasan eksplisit tentang bagaimana suatu ujaran mempunyai makna lebih daripada ujaran bahasa itu sendiri dan pemakai bahasa pun mamahami makna tersebut. Ketiga, implikatur mampu menyederhanakan deskripsi semantik dari hubungan antar klausa, meskipun klausaklausa itu dihubungkan dengan kata yang sama. Keempat, dengan konsep implikatur dapat diterangkan berbagai macam fakta kebahasaan yang secara lahiriah kelihatan tidak berkaitan atau bahkan berlawanan, seperti bekerjanya metafora, tautology, dan ironi.

Grice (1975) membedakan adanya tiga macam implikatur, yaitu implikatur konvensional, implikatur percakapan, dan praanggapan. Implikatur konvensional mengandung implikasi pragmatik yang diperoleh langsung dari makna kata, bukan dari prinsip-prinsip percakapan (Leech, 1989). Sedangkan praanggapan yaitu prasarat yang memungkinkan suatu pernyataan benar atau tidak benar. Prasarat itu mendukung hubungan antara pembicara dan kewajaran suatu kalimat dalam suatu konteks tertentu.

Lebih jauh Samsuri (1987) mengemukakan bahwa implikatur percakapan dipakai untuk memperhitungkan apa yang dapat disarankan atau dimaksud oleh pembicara sebagai pembeda dari apa yang dimaksudkan secara harfiah. 
Dari berbagai pandangan tentang implikatur yang telah dikemukakan, dapat dipahami bahwa sebuah wacana berupa percakapan, jika dicermati mengandung unsur-unsur lingual, aplikasi, karakteristik tertentu, kerjasama, sopan santun, kemunculan. Dengan demikian, analisis dan deskripsi dalam penelitian ini difokuskan pada unsur-unsur tersebut.

Teori pemerolehan bahasa kedua diwarnai oleh tiga aliran : bihaviorisme, nativisme, dan interaksionisme (Baradja, 1992). Larsen-Freeman dan Long (1991) mengatagorikan teori-teori pemerolehan bahasa menjadi tiga golongan besar : teori naives, teori lingkungan, dan teori interaksionis. Kaum natives memandang bahwa pemerolehan bahasa merupakan hasil kerja mekanisme bawaan khusus bahasa dan hal itu hanya dapat ditemukan pada manusia (Clark dan Clark, 1997). Tokoh aliran ini, Chomsky mengemukakan bahwa mekanisme bawaan itu terjadi pada alat pemerolehan bahasa (Language Acquisition Device/LAD) yang memungkinkan manusia belajar bahasa. Tanpa adanya anugerah bawaan itu, pembelajaran bahasa tidak mungkin terjadi karena data masukan tidak cukup untuk pemerolehan.

Teori lingkungan menganggap bahwa pengalaman organisme lebih penting daripada organisme bawaan itu sendiri. Penganut teori ini memandang bahwa lingkunganlah yang membentuk perkembangan makhluk dan hal itu tidak ada kaitannya dengan factor bawaan. Selanjutnya teori interaksionis lebih unggul dalam menjelaskan pemerolehan bahasa karena teori ini menggabungkan pentingnya peran faktor bawaan dan faktor lingkungan sebagai penentu terjadinya proses belajar bahasa pada diri pembelajar. Teori ini memandang bahwa penguasaan bahasa terjadi berkat adanya interaksi antara masukan bahasa yang dipajankan kepada pembelajar dan kemampuan internal yang dimiliki oleh pembelajar.

Bukti-bukti menunjukkan pentingnya antara interaksi masukan dan LAD. Penguasaan bahasa terjadi karena adanya kebutuhan pemelajar untuk berkomunikasi dengan orang lain. Teori ini memberi peran yang lebih banyak pada latihan-latihan yang bersifat interaktif seperti bertanya dan menjawab yang banyak terjadi dalam percakapan antara penutur dan petutur. Sehubungan dengan hal itu, Long (1981) mengemukakan pentingnya interaksi dalam pemerolehan bahasa sasaran (lihat juga Baradja, 1990 ; 1992). Secara tertulis percakapan banyak terdapat di buku-buku teks pelajaran bahasa Inggris, cerita pendek, dan novel yang dapat dijadikan sumber kajian implikatur. 


\section{METODE PENELITIAN}

Penelitian ini adalah penelitian pragmatik yang bertumpu pada analisis wacana. Desain penelitian yang digunakan untuk mendeskripsikan seluk-beluk implikatur percakapan tertulis bahasa Inggris SMA yang mencakup bentuk, konteks, dan keterkaitannya dalam percakapan. Peneliti tidak membuat perlakuan dan tidak juga menggunakan statistic dalam analisis data. Peneliti tidak menggunakan pendekatan kuantitatif, tetapi menggunakan pendekatan kualitatif. Hal itu tampak selain pada tujuan, juga pada data yang dikumpulkan yang tidak berupa angka, tetapi berupa wacana, tuturan, kalimat, ataupun kata-kata.

Penelitian ini bertujuan mendeskripsikan bagaimana implikatur percakapan dalam bahasa Inggris diekspresikan atau diungkapkan dalam waktu tertentu, dalam periode tertentu, tidak melihat bagaimana perkembangan penguasaan itu dari waktu ke waktu. Karena hanya memotret objek dalam suatu waktu (sesaat), penelitian ini bukan penelitian longitudinal, melainkan cenderung dapat dikategorikan sebagai penelitian kroseksonal atau penelitian silang. Karena sifatnya deskriptif kuantitatif, penelitian ini tidak menggunakan hipotesis sebagai jawaban tentatif terhadap masalah penelitian. Landasan teori pada tinjauan pustaka tidak dimaksudkan sebagai dasar yang mengikat gerak peneliti, serta akhirnya bermuara pada suatu hipotesis alteratif yang perlu diverifikasi dengan data empiris. Landasan teori berfungsi sebagai bekal wawasan bagi peneliti untuk menggeluti ihwal implikatur percakapan bahasa Inggris tertulis sebagai bahasa asing yang diajarkan secara formal di sekolah.

Untuk sampai pada tujuan penelitian, diperlukan adanya dua macam data penelitian. Pertama, data berupa wacana percakapan tertulis yang diambil dari percakapan atau dialog yang melibatkan dua atau lebih komunikan dalam komunikasi verbal, dengan tanpa melihat atau mengamati gerak-gerik anggota tubuh komunikan. Kedua, data yang berupa informasi interpretasi tentang bagaimana implikatur di ekspresikan dalam konteks percakapan yang dikaji.

Data penelitian ini diperoleh dari data yang berupa percakapan tertulis yang diambil dari buku teks pelajaran bahasa Inggris SMA kelas I terbitan Yudistira. Percakapan atau petikan percakapan diambil sebanyak kemunculan unsur-unsur implikatur yang diperlukan sesuai masalah penelitian yang dirumuskan. Oleh karena data yang diambil hanya dari satu buku teks pelajaran maka penelitian ini termasuk pada penelitian kasus. 


\section{HASIL DAN PEMBAHASAN}

Sesuai dengan tujuan penelitian ini untuk mengungkap/ mendeskripsikan seluk beluk, bentuk, dan keterkaitan implikatur percakapan tertulis dalam buku teks pelajaran bahasa Inggris SMA sebagai sumber belajar dan siswanya sebagai pemelajar serta pengguna bahasa Inggris, telah diperoleh data/korpus dalam bentuk percakapan tertulis. Data ini diperoleh dari petikan (kutipan) dialog secara acak yang terdapat di dalam buku teks pelajaran dengan judul English Alive Senior High School yang diterbitkan oleh penerbit Yudhistira. Namun untuk kepentingan penyajian dan penjelasan dalam hasil dan pembahasan inti, tidak seluruh data disajikan melainkan berupa petikan-petikan yang langsung mengandung implikatur.

Petikan Dialog (percakapan)

Sandra : Hello, I'm calling for a friend about your ad for apartment. Is it still available?

Manager : Yes, it is. Would you like to see it?

Sandra : Yes, I'd like too. Can I get the address?

Manager : 1401 Pinewood Drive. It's on the corner of Pinewood Drive and Landcaster Boulevard.

Sandra : Great! That's near the beautiful beach. When can I come over?

Manager : Right now, if you like, but if not, you may come some other time. Drive up to the first building on the right. My office is on the first floor.

Sandra : Alright.

Dalam petikan percakapan ini terdapat empat untaian tuturan antara Sandra dan Manager. Nampaknya percakapan ini dipicu oleh adanya iklan untuk menyewakan sebuah apartemen, namun tidak diketahui dimana iklan itu didapat, apakah di televisi, koran, atau media lainnya. Nampaknya baik Sandra maupun Manager (sebagai penutur dan petutur) menurut Coulthard (1983), sudah sama-sama mengetahui dimana iklan itu berada atau didapat. Karena itu pada T1 (tuturan 1) dapat diketahui bahwa penutur langsung menanyakan apartemen yang diiklankan. Hanya saja si penutur tidak yakin apakah apartemen masih ada, belum ada yang menyewa atau sudah disewakan kepada orang lain. Oleh karena itu, penutur meminta kepastian dengan menggunakan kalimat tanya, Is it still available? Sebagai implikatur yang berimplikasi adanya jawaban ya atau tidak. 
AKSARA Jurnal Bahasa dan Sastra

Vol. 19, No. 1, Hal. 37 - 53, April 2018

http://jurnal.fkip.unila.ac.id/index.php/aksara

T1 Sandra : Hello, I'm calling for a friend about your ad for apartment. Is it still available?

Manager : Yes, it is. Would you like to see it?

Lebih lanjut manager sebagai petutur memberi kepastian dengan respons, Yes, it is. Petutur dalam hal ini memberi kesempatan untuk melanjutkan dialognya dengan memberi pertanyaan, Would you like to see it? Sebagai implikatur uyang secara kontekstual merujuk kepada makna menyuruh melihat (perintah). Implikasi dari pertanyaan itu adalah penegasan jawaban, yes pada T2.

T2 Sandra : Yes, I'd like too. Can I get the address?

Manager : 1401 Pinewood Drive. It's on the corner of Pinewood Drive and Landcaster Boulevard.

Ungkapan I' like too, setelah Yes tidak mengandung makna apa-apa, melainkan hanya sebagai komplemen dari jawaban penegasan Yes. Sebagai inisiator penutur, Sandra menyatakan kesanggupannya untuk mendatangi alamat dimana apartemen yang diiklankan. Karena itu, frasa the address sebagai implikatur secara kontekstual mengacu kepada alamat apartemen yang diiklankan sebagaimana dinyatakan dalam T1. Sebagai konsekwensi atau implikasi frasa the address pada pertanyaan, Can I get the address? Maka muncullah frasa 1402 Pinewood Drive. Berdasarkan prinsip interpretasi lokal, frasa tersebut belum memenuhi prinsip kerjasama yang saling dikehendaki oleh kedua belah pihak, penutur dan petutur. Oleh karena itu petutur memberi informasi lanjutan, It's on the corner of Pinewood Drive and Lancaster Boulevard, sebagai petunjuk dan mengarah kepada T3 seperti berikut.

T3 Sandra : Great! That's near the beautiful beach. When can I come over?

Manager : Rigt now, if you like, but if not, you may come some other time. Drive up to the first building on the right. My office on the first floor.

Dari T3 dapat diketahui bahwa kata Great! Merupakan ekspresi kegembiraan (delightness) antusiastik. Hal ini diekspresikan karena si penutur sudah mengetahui bahwa alamat yang disampaikan oleh petutur menyenangkan letaknya dekat pantai yang indah. Secara logis diketahui bahwa orang umumnya senang dengan keadaan pantai yang indah. Sebagai penutur, Sandra, tetap berinisiasi untuk melanjutkan dialog dengan mengajukan pertanyaan, When can I come over? Yang merupakan implikatur dalam T3 tersebut. Implikatur ini berimplikasi pada adanya permintaan 
jawaban. Oleh petutur pertanyaan itu diberi jawaban dua alternatif. Alternatif pertama, right now yang merupakan adanya tindakan langsung; dan alternatif kedua yang menawarkan tindakan tunda (delayed action) seperti terungkap dalam tuturan, If you like, but if not, you may come some other time. Namun demikian, pada T3 ada perintah, Drive up the first building on the right sebagai implikatur yang berimpllikasi agar si penutur langsung datang menemui si petutur saat iru juga sebagaimana terungkap dalam perintah tersebut. Hal ini mengindikasikan tindakan langsung meskipun perintah itu disadari atau tidak oleh penutur (Kasper, 2011). Perintah tindakan langsung itu diperkuat dengan informasi yang diperluas, My office is on the first floor. Dari tautan T3 ke T4 dapat diketahui dengan jelas bahwa implikatur yang berbentuk perintah, Drive up ... itu memberikan implikasi jawaban persetujuan sebagaimana terekspresikan pada kata, Alright yang merupakan T4.

T4 Sandra : : Alright.

Dalam T4 hanya ada penutur (Sandra) dan tidak ada petutur, karena kata alright merupakan jawaban akhir serta hasil kerjasama antara penutur dan petutur. Dengan demikian kata Alright pada T4 sebagai implikatur yang berimplikasi pada kesepakatan (agreement) dari petikan percakapan secara keseluruhan.

\section{Bentuk Lingual Implikatur yang Muncul}

Setelah dilakukan pengamatan dan pengkajian terhadap data dari petikan-petikan percakapan dapat diketahui bahwa dari 15 data implikatur yang dikaji dan digunakan oleh subjek muncul secara lingual dalam bentuk kata, frase, klausa dan kalimat.

Berikut ini disajikan data implikatur yang secara lingual dalam bentuk kata.

1. Student A : Can I see yours? I haven't finished mine.

$$
\text { B }: \underline{O K} .
$$

2. Teacher : Please. Well everybody. Collect your homework (the student in the class are collecting the homeworsk to teacher, but a student (student C) gave a response.

Student C : I'm sorry sir. My homework is left at home.

Teacher : What?

Student C : Left.

3. Teacher : Alright. Who knows the answer?

Student D : (while pointing out her finger) It is for children of all people.

Teacher : Good. 
Student D : $\underline{\text { Yes. }}$.

Untuk dapat memahami implikatur pada kata $\underline{O K}$ pada percakapan 1, kata what pada percakapan 2, dan kata good pada percakapan 3 diperlukan deskripsi topik, situasi, dan konteks dan masing-masing petikan percakapan tersebut.

Petikan percakapan 1 ,

Situasi : Percakapan ini terjadi pada jam istirahat setelah jam ke-3. Jam berikutnya (jam ke-4) adalah pelajaran bahasa Inggris. Guru bahasa Inggris telah memberi tugas (homework) minggu sebelumnya. Ketika jam istirahata student A ingat kalau ada tugas bahasa Inggris pada jam ke-4. Dia segera mendekati student B dan bertanya pada student B. Student B menjawab $\underline{O K}$ (sambal masuk ke kelas mengambil tugasnya dan memberikannya pada student A).

Topik : Topik percakapannya adalah homework yang telah diberikan guru minggu sebelumnya

Konteks : Homework yang ditugaskan guru harus dikerjakan di rumah dan harus diserahkan pada jam ke-4. Kalau ada siswa yang tidak menyerahkan homework guru itu biasanya marah. Oleh karena itu student A berusaha keras bagaimana supaya dapat menyerahkan homework pada jam ke-4.

Petikan percakapan 2,

Situasi : Percakapan ini terjadi pada jam ke-4 setelah guru bahasa Inggris masuk kelas. Guru meminta agar semua murid mengumpulkannya. Namun tiba-tiba ada seorang siswa (student $C$ ) yang merespon bahwa dia tidak membawa tugasnya karena tertinggal dirumah. Lantas dengan nada marah guru mengatakan what? Dan student $\mathrm{C}$ menegaskan left.

Topik : Topik pada percakapan 2 sama dengan percakapan 1, yaitu homework.

Konteks : Meskipun topiknya sama antara petikan 1 dan 2, namun konteksnya berbeda. Konteks percakapan pada 2 adalah menyerahkan homework pada waktu yang sudah ditentukan.harapan guru tidak seorang siswapun tidak menyerahkan tugasnya.

Petikan percakapan 3, 
Situasi : Saat itu guru sedang menugasi siswa untuk membaca teks pada jam ke-4. Setelah beberapa menit guru mengajukan pertanyaan-pertanyaan. Ternyata ada pertanyaan yang tidak bisa terjawab oleh siswa di kelas itu. Lantas guru menyuruh siswa membaca teks sekali lagi dengan konsentrasi pada satu jawaban yang belum terjawab tersebut. Setelah beberapa saat guru menanyakan kembali pertanyaan itu. Lalu ada seorang siswa (student D) unjuk tangan dan menjawab dengan benar.guru merespon jawaban ini dengan ekspresi good. Dan siswa D merespon yes.

Dari deskripsi situasi, topik dan konteks untuk petikan percakapan 1, 2 dan 3 dapat dijelaskan/diterangkan implikatur yang terkandung dalam kata $O K(1)$, left (2), dan yes (3).

Leech (1989) menyatakan bahwa bentuk lingual percakapan ditentukan maknanya oleh situasi dan konteks dengan topik sebagai acuan. Pada petikan percakapan 1, bentuk lingual implikaturnya adalah kata $O K$. Kata $O K$ di sini berimplikasi pada persetujuan. Student B setuju untuk memberikan homeworknya kepada student A (temannya). Ini menunjukkan adanya maksim CP (Cooperative Prinsiple). Dilihat dari maksim CP maka pernyataan $O K$ merupakan jawaban $\uparrow$ s (desirable for the speaker), yaitu suatu jawaban yang dikehendaki oleh student A.

Demikian pula pada petikan percakapan 2, bentuk lingual implikaturnya adlah kata $\underline{\text { left}}$, yang secara gramatikal merupakan maksim kata kerja. Berdasarkan situasi,topik dan konteksnya kata left berimplikasi pada kata my homework pada konteks pernyataan sebelumnya, yang dinyatakan pada pernyataan "My homework is left at home”. Sebetulnya kata what yang diucapkan oleh Teacher merupakan maksim tanya (question word) yang berimplikasi pada seluruh pernyataan "I'm sorry sir. My homework is left at home”. Jadi ada dua kata implikatur (what, diucapkan oleh teacher dan left, diucapkan oleh student C) pada petikan percakapan 2.

Pada petikan percakapan 3 bentuk lingual implikatur yang diproduksi oleh student D adalah kata "yes", yang secara gramatikal merupakan kata sebagai short answer. Tetapi secara fungsional komunikatif pernyataan "yes" merupakan penegasan (assertion) terhadap reward yang diberikan oleh Teacher. Berdasarkan situasi, topik, dan konteksnya, katayes berimplikasi pada pernyataan "It is for children of all 
people". Jadi baik maksim lingual kata good maupun yes mengacu dan berimplikasi pada pernyataan "It is for children of all people".

\section{Karakteristik Hubungan antara Implikatur Percakapan}

Ditinjau dari hubungan, maksim relevansi mengharuskan setiap peserta tutur memberikan kontribusi yang relevan dengan pembicaraan (Hasani, 2005). Dari data yang dijadikan sampel (petikan percakapan 1) antara implikatur dan implikasinya mempunyai hubungan langsung (direct relation). Antara pertanyaan/permintaan student A "Can I see yours? I haven't finished mine" dan reaksi ilokusinya (respon dari student B) dengan kata $O K$ tidak ada antara/penyela. Ini berarti terjadi direct mutual CP ; antara speaker dan hearer memiliki praanggapan yang sama. Dalam konteks ini tidak terjadi semantikal transition.

Pada data 2 dan 3 (petikan percakapan 2 dan 3) hubungan implikatur dan implikasinya tersela oleh adanya transitional signal baik secara semantik maupun linguistik.pada petikan percakapan 2 pernyataan "I'm sorry sir. My homework is left at home" oleh student $\mathrm{C}$ dan assertive determination "left" juga oleh student $\mathrm{C}$, ada penyela expressive question "what" oleh teacher. Oleh karena itu hubungan ini termasuk indirect relation. Dan penyela antara implikatur dan implikasi ini berupa question word "what" yang menurut Leech (1989) dapat digolongkan/disebut sebagai semantic respressentaion of interrogative. Secara semantik baik implikatur "what" yang diekspresikan oleh teacher dan implikatur "left" yang diproduksi oleh student C "I'm sorry. My homework is left at home". Tetapi secara gramatikal mempunya bentuk yang berbeda : what sebagai question word, sedangkan leftsebagai verb. Oleh karena itu, hubungan kedua implikatur ini juga dapat dikatakan secara fungsional sebagai hubungan sentral atau terfokus.

Pada petikan percakapan 3, pernyataan jawaban "It is for children of al people" oleh student D disela dengan honoratif ilokusi sifat "good" dari teacher. Dengan demikian sifat hubungan implikatur yes dan implikasinya "It is for children of all people"yang sama-sama diproduksi student D adalah emphatically indirect relation. Secara semantik terkait, tapi secara gramatikal terpisah antara implikatur dan implikasinya pada petikan percakapan 3 . 


\section{Hubungan Implikatur dalam Percakapan}

Dalam analisis pragmatik prinsip-prinsip kesopanan perlu diketahui/dijelaskan agar tidak terjadi "communication break" antara speaker dan hearer (pembicara dan pendengar) (Leech, 1989). Seperti diketahui untuk bisa terlibat dalam percakapan secara aktif harus ada kesepahaman dan ketertarikan dari semua komunikan yang terlibat dalam percakapan.

Berikut ini petikan percakapan 4 sebagai sampel data untuk menjelaskan PP (Politeness Principle $=$ prinsip sopan santun).

4. Student E : May I help you Sir?

Teacher : Yes. Of course.

Student E : Where should I put it Sir?

Teacher : On my desk.

Situasi : Hari itu pelajaran bahasa Inggris berakhir. Setelah menutup pelajaran guru keluar kelas sambal membawa bubu-buku dan alat peraga. Saat itu ada seorang siswi yang memperhatikan dan peduli sehingga menawarkan diri untuk membantu guru itu membawa buku-bukunya dan alat peraga untuk diletakkan di meja guru tersebut (di ruang guru).

Topik : : Guru membawa sendiri buku-bukunya.

Konteks : Hubungan guru-murid dalam situasi atau konteks sekolah diwarnai oleh prinsip sopan santun.

Dari petikan percakapan 4 diketahui bahwa student E menggunakan maksim kwalitas "may" menawarkan diri (jasa) pada gurunya. Penggunaan may secara gramatikal sebagai "penghalus" tindak tutur. Secara metalinguistik student memiliki praanggapan bahwa murid harus bertutur sopan terhadap gurunya. Oleh karena itu student $\mathrm{E}$ memilih may sebagai tawaran jasa yang mungkin diterima atau mungkin tidak diterima.

Dalam pernyataan "Where should I put it Sir?", student E menggunakan illocutionary force "should" untuk memperoleh kepastian/keputusan tentang tempat menaruh bawaannya (buku dan alat peraga). Dengan penggunaan kata should sebagai implikatur, student $\mathrm{E}$ dapat memperoleh determinasi tentang penggunaan kata tanya where. Penggunaan maksim kwalitas should dalam konteks ini mempunyai fungsi ganda: pertama sebagai penegas dan kedua sebagi penghalus (sopan santun). Pemahaman ini ditandai dengan respon langsung (tanpa pikir lebih lanjut) oleh 
teacher dengan mengatakan "Onmy desk". Ini berarti adakesepahaman tentang implikasi yang ditimbulkan pengguna implikatur should. Dalam konteks ini dapat dikatakan terjadi relasi hormone antara pembicara dan pendengar.

Bila dibandingkan dengan percakapan 2, sesungguhnya terjadi relasi disharmony antara teacher dan student $C$ dalam prinsip sopan santun, karena tidak selayaknya seorang siswa melalaikan tugas yang telajh diberikan oleh guru. Akan tetapi prinsip directness (tindak tutur yang tidak berbelit) tercapai, sehingga guru tidak harus mencari/memproduksi bentuk ekspresi lingual lanjutan.

\section{Konteks Kemunculan Implikatur Percakapan}

Seperti dinyatakan oleh Leech (1989) bahwa konteks sangat menentukan makna inferensial pada percakapan. Dilihat dari segi formalitas dan fungsional dari implikatur-implikatur yang teridentifikasi dari petikan-petian percakapan, dapat diketerangkan bahwa implikatur muncul karena adanya prinsip kerjasama (cooperative principle) dan prinsip sopan santun (politeness principle). Dalam data tidak ditemukan implikatur yang muncul karena prinsip ironi (irony principle). Hal ini agaknya dipengaruhi oleh konteks formal (interaksi kelas). Karena situasinya formal percakapan siswa dan guru, guru dengan siswa, dan antar siswa maka pemilihan penggunaan lingual baik bentuk kata, frase, klausa, maupun kalimat cenderung ketat (strict pada pertimbanga grammatical correctness daripada communicative smoothness.

Secara fungsional impikatur yang muncul dari data yang dijadikan dampel (korpus) juga Nampak dipengaruhi prinsip unggah-unggah. Masing-masing komunikan (pembicara dan pendengar) daling mempertahankan posisinya baik sebagai siswa maupun sebagi guru dan antar sesame siswa. Tidak ada kecenderungan prinsip kesejajaran atau bahkan kebebasan dalam penggunaan maksim. Hal ini akan sangat berbeda bila percakapan terjadi dalam konteks tidak formal (bebas). Kemungkiinan penggunaan maksim akan semakin leluasa. Walaupun bentuk harfiahnya penyangkalan dalam "I'm sorry Sir. My homework is left at home" namun secara semantik bermakna tidak tutur deklaratif (informasi positif) bagi penutur (student C) pada petikan percakapan 2 . 


\section{KESIMPULAN DAN SARAN}

Sebagai jawaban dari pertanyaan-pertanyaan yang diajukan dalam perumusan masalah dalam, berdasarkan hasil analisis dan deskripsi data dapat ditarik kesimpulan sebagai berikut.

1. Bentuk lingual implikatur percakapan bahasa Inggris SMA bervariasi dari kata, frase, klausa, sampai kalimat.

2. Implikasi pragmatis yang ditimbulkan oleh percakapan tertulis dalam bahasa Inggris SMA umumnya mengarah pada kesepahaman dan directness (keterusterangan) antara penutur dan petutur.

3. Karakteristik hubungan antar implikatut percakapan tertulis dalam bahasa Inggris SMA dan implikasinya ditandai dengan penggunaan maksim gramatikal yang ketat, tidak bebas/leluasa.

4. Hubungan antara implikatur percakapan tertulis bahasa Inggris SMA dan prinsip sopan santun adalah hubungan formal-fungsional, hormatmenghormati, saling mempertahankan posisinya.

5. Konteks kemunculan implikatur percakapan tertulis dalam bahasa Inggris SMA dipengaruhi adanya kebutuhan kesalahpahaman dan ketercapaian maksud dari masing-masing komunikan (penutur dan petutur).

Dari kesimpulan-kesimpulan tersebut dapat disarankan agar pembelajaran bahasa Inggris banyak diciptakan situasi yang variatif, tidak monoton dalam situasi formal dari guru. Perlu disadarkan pada siswa agar dalam percakapan menggunakan maksim-maksim komunikatif yang fleksibel, tidak grammatically correctnessoriented dengan topik-topik bebas, pilihan dari siswa (tidak selatu ditentukan oleh guru) dalam buku teks pelajaran.

Bagi peneliti yang tertarik untuk mengungkap seluk-beluk implikatur percakapan dalam bahasa Inggris di luar kelas untuk menjamin kealamian dan fleksibilitas percakapan, yang terkait dengan language acquisition, dan bukan semata-mata language learning. Karena itu, berbagai percakapan atau dialog yang ada di dalam buku teks pelajaran dapat dimodifikasi dan disesuaikan dengan situasi dan kondisi nyata di lingkungan para pemelajar. 


\section{DAFTAR PUSTAKA}

Baradja, M.F. (1990). Kapita Selekta Pengajaran Bahasa. Malang: Penerbit IKIP Malang. . (1992). Perkembangan Teori Pemerolehan Bahasa Kedua dalam Kaitannya dengan Proses Belajar-Mengajar. Forum Penelitian, 4 (1 dan 2): 41-62.

Depdikbud. (1994). Kurikulum Pendidikan Dasar: Garis-garis Program Pengajaran $(G B P P)$. Jakarta: Depdikbud.

Depdiknas. (2003). Kurikulum 2004 SMA: Pedoman Khusus Pengembangan Silabus dan Penilaian Mata Pelajaran Bahasa Inggris. Jakarta.

Grice, H.P. (1975). “Logic and Conversation,” In Cole and Morgan (Eds.), 41-58.

Harnish, R.M. (1991). Logical Form and Implicature. Dalam Davish, S. (Ed.), Pragmatiks: A reader (hlm.316-364). New York: Oxford University Press.

Kasper, Gabriele. (2011). Locating Politeness in Interaction. Jakarta: MLI Tahun ke 29 (1): 1-17.

Kaswanti Purwo, B. (1984). Deiksis dalam Bahasa Indonesia. Jakarta: Balai Pustaka. Karomani. (2011). Keterampilan Berbicara 2. Tanggerang: Matabaca Publishing. . (1990). Pragmatik dan Pengajaran Bahasa: Menyibak Kurikulum 1984. Jakarta: Kanisius.

Lansen-Freeman, D. dan Long, M. H. (1991). An Introduction to Second Language Acquisition Research. London: Longman.

Leech, G. (1981). Semantic: The Study of Meaning. Great Britain: Penguin Books. . (1989. Principles of Pragmatics. London: Longman.

Levinson, S. C. (1987). Pragmatics. New York: Cambridge University Press.

Nababan, P. W. J. (1987). Ilmu Pragmatik (Teori dan Penerapannya). Jakarta: Depdikbud.

Refnaldi. (2009). Transfer Pragmatik dalam Respon terhadap Pujian dari Bahasa Indonesia ke dalam Bahasa Inggris. Jakarta: MLI Tahun ke 27 (2): 175-196.

Samsuri. 1987. Analisis Wacana. Malang: IKIP Malang. 